\title{
Contribution of fish farming to the nutrient loading of the Mediterranean*
}

\author{
IOANNIS KARAKASSIS ${ }^{1}$, PARASKEVI PITTA ${ }^{2}$ and MICHAEL D. KROM ${ }^{3}$ \\ ${ }^{1}$ University of Crete, Department of Biology, PO Box 2208, Heraklion 71409, Greece. E-mail: karakassis@biology.uoc.gr \\ ${ }^{2}$ Institute of Marine Biology of Crete, PO Box 2214, Heraklion 71003, Greece. \\ ${ }^{3}$ School of Earth Sciences, Leeds University, Leeds LS2 9JT, United Kingdom.
}

\begin{abstract}
SUMMARY: Mediterranean fish farming has grown exponentially during the last 20 years. Although there is little evidence of the impact on the trophy status around fish farms, there are concerns that the release of solute wastes from aquaculture might affect larger scales in the ecosystem by changing the nutrient load. After combining information from various sources on waste production and on nutrient loads, it was concluded that the overall $\mathrm{N}$ and $\mathrm{P}$ waste from fish farms in the Mediterranean represents less than 5\% of the total annual anthropogenic discharge, and the overall annual increase in P and $\mathrm{N}$ pools in the Mediterranean, under a production rate of 150000 tons, is less than $0.01 \%$. The proportion of fish farming discharged nutrients was slightly higher in the eastern Mediterranean. A simple model was used to assess the long-term effects of nutrients released from various sources taking into account the water renewal rate in the Mediterranean. We conclude that, in the long term, fish farm waste could cause a $1 \%$ increase in nutrient concentrations in contrast to other anthropogenic activities which might double the Mediterranean nutrient pool.
\end{abstract}

Keywords: Mediterranean, nutrients, cage farming, anthropogenic eutrophication.

RESUMEN: CONTRIBUCIÓN DE LAS GRANJAS DE PECES A LA CARGA DE NUTRIENTES DEL MEDITERRÁNEO. - La piscicultura en el Mediterráneo ha crecido exponencialmente durante los ultimos 20 años. Aunque hay pocas evidencias del impacto sobre el estado trófico alrededor de las granjas de peces, existe la preocupación de que la liberación de residuos solubles procedentes de la acuicultura pueda afectar al ecosistema, de manera notable, a través de cambios en la carga de nutrientes. Después de combinar información de varias fuentes sobre la producción de residuos cargados de nutrientes, se concluyó que el $\mathrm{N}$ y el $\mathrm{P}$ totales liberados en las granjas de peces en el Mediterráneo, representan menos del 5\% de la descarga anthropogénica anual total y el aumento anual del contenido en $\mathrm{P}$ y de $\mathrm{N}$ en el mediterráneo, bajo una tasa de producción de 150000 toneladas, es menor de $0.01 \%$. La proporción de la descarga de nutrientes procedentes de la piscicultura fue ligeramente mayor en el Mediterráneo Oriental. Se utilizó un modelo sencillo para determinar los efectos, a largo plazo, de la liberación de nutrientes desde varias fuentes considerando la tasa de renovación del agua en el Mediterráneo. Se concluyó que, a largo plazo, las granjas de peces podrían dar lugar a un aumento del $1 \%$ de las concentraciones de nutrientes, en contraste con otras actividades antropogénicas que podrían doblar el contenido de nutrientes del Mediterráneo.

Palabras clave: Mediterráneo, nutrientes, granjas de peces, eutroficación antropogénica.

\section{INTRODUCTION}

Fish farming interacts with the marine environment at various spatial and temporal scales. Silvert (1992), has classified these impacts as internal

*Received May 25, 2004. Accepted November 9, 2004. (effects of a particular farm on itself and its immediate environment), local (impacts that affect nearby farms and wild populations within distances in the order of a kilometre) and regional (impacts involving an entire inlet or larger water body with spacial scales of many kms and time scales ranging from a single tidal cycle to an entire season). However, 
there have been concerns that the effluents from aquaculture might have even larger scale impacts due to the rapid expansion of the industry in the coastal zone. GESAMP (1990), described mariculture as a potential source of eutrophication for the marine environment. The European Environment Agency report on the state of the Marine Environment in the Mediterranean (Gabrielides et al., 1999), presented the total amount of nutrient discharge in the Mediterranean due to fish farming, implying that there is some potential for hypernutrification (excessive increase in nutrient concentration) or even eutrophication (significant increase in primary production) due to aquaculture expansion. Moreover, Naylor et al. (2000), discussed nutrient pollution from aquaculture wastes which exceed the assimilative capacity of receiving waters, therefore leading to deterioration in water quality.

The Mediterranean has experienced an almost exponential increase in fish farming production during the last 20 years, but until 1994 there was limited information on the environmental impact of the fish farming industry in the Mediterranean (Munday et al., 1994). During the last five years, there has been some progress in understanding these processes in the Mediterranean through a series of published papers concerning the impact of fish farming on water column chemistry and parasites (Papoutsoglou et al., 1996), the effects on nutrients and plankton (Pitta et al., 1999; Karakassis et al., 2001), the effects on seagrass (Delgado et al., 1999; Pergent et al., 1999; Ruiz et al., 2001), the dynamics of sediment accumulation beneath fish farm cages (Karakassis et al., 1998), the recovery process of the benthos after cessation of fish farming (Karakassis et al., 1999), and the effects on sediment geochemistry and benthic organisms (MacDougal and Black, 1999; Karakassis et al., 2000, 2002; Karakassis and Hatziyanni 2000; Mazzola et al., 1999; 2000; La Rosa et al., 2001; Mirto et al. 2002). These studies involved monitoring environmental variables at one or more fish farms in different regions within the Mediterranean and have shown that there are small to moderate effects on the immediate vicinity of the fish farms. In most cases fish farms are sited in locations with high water flushing rates. This results in the nutrients being exported away from the immediate vicinity of the cages. However, it is worth considering whether the continuous export of nutrients from hundreds of sites along the Mediterranean coast, with continuously increasing production is likely to affect the quality of the water at a large scale as implied by Gabrielides et al. (1999), and as feared by many environmentalists. Bethoux et al. (1998), have found an increase in nutrient content in deep water in the western Mediterranean and suggested that it is due to anthropogenic inputs. Similar long-term data is not available at present for the eastern basin to see if similar changes have also taken place there. It is the aim of this study to assess whether the additive effect of fish farming could contribute significantly to the nutrient budget and hence to environmental change at very large spatial scales. Water quality at mesoscales $(10-100 \mathrm{~km})$ is influenced by the amount of local discharges as well as by the quality of the ambient water reservoir where "pure" water (i.e. not directly affected by the local discharges) enters the system replacing the locally enriched water masses. In this context it is worth knowing what is the quality of the water at larger scales and whether local effects accumulate causing a significant change in ambient conditions.

In the present paper we have combined available information on seabream and seabass production and other anthropogenic discharges as well as oceanographic data on nutrient pools in the Mediterranean. A simple mathematical model was used in order to obtain meaningful estimates and predictions of the potential impact of fish farming on nutrient content in the Mediterranean.

\section{MATERIALS AND METHODS}

\section{Nutrient discharge}

Detailed mass balance models for the salmonids have been provided by Hall et al. (1992), and Holby and Hall (1991), and a number of papers have reported values for nutrient release of different marine fish species including seabream and seabass (Table 1). In all cases the amount of nutrients recovered through harvest is less than $1 / 3$ of that supplied through the fish feed, but there is considerable variability in the estimates of the proportion of the solute fraction of the wasted part. This variability probably reflects local conditions (such as temperature and oxygen availability) whereas the variability in harvestable proportion reflects both species-related biological factors and management factors. Based on this information, we have chosen an upper and a lower proportion figure ("working figures" in Table 1), which seem to be reasonable estimates of the nutrients lost to the environment ignoring one 
TABLE 1. - Estimates of the percentage of nutrients recovered through harvesting and lost to the environment during marine fish farming. Total waste $(\%)$ includes both particulate and dissolved waste; dissolved waste includes only nutrients released into the water column.

\begin{tabular}{|c|c|c|c|c|c|c|c|}
\hline \multirow[t]{2}{*}{ Source } & \multirow[t]{2}{*}{ Species } & \multicolumn{2}{|c|}{ Harvested (\%) } & \multicolumn{2}{|c|}{ Total wasted (\%) } & \multicolumn{2}{|c|}{ Dissolved (\%) } \\
\hline & & $\mathrm{N}$ & $\mathrm{P}$ & $\mathrm{N}$ & $\mathrm{P}$ & $\mathrm{N}$ & $\mathrm{P}$ \\
\hline Hall et al., 1992 & trout & 28 & & 73 & & 50 & \\
\hline Holby and Hall, 1991 & trout & & 18 & & 82 & & 34 \\
\hline Gowen and Bradbury, 1987 & salmon & 25 & & 75 & & 52 & \\
\hline Folke and Koutsky, 1989 & salmonids & 25 & 23 & 75 & 77 & 62 & 11 \\
\hline Ballestrazzi et al., 1994 & seabass & & & & & $31-34$ & $17-29$ \\
\hline Dosdat et al., 1996 & seabass & & & 77 & & $43-47$ & \\
\hline Krom et al., 1985 & seabream & 36 & 29 & 64 & 71 & & \\
\hline Porter et al., 1987 & seabream & 30 & & 70 & & 60 & \\
\hline Krom et al., 1995 & seabream & 25 & & 75 & & 60 & \\
\hline Dosdat et al., 1996 & seabream & & & & & $43-55$ & \\
\hline Lanari et al., 1999 & seabass & $18-21$ & $25-41$ & $79-82$ & $59-75$ & & \\
\hline Kaushik, 1998 & seabass & & $45-55$ & & $45-55$ & & \\
\hline Kaushik, 1998 & seabream & & $51-63$ & & $38-49$ & & \\
\hline Lupatsch and Kissil, 1998 & seabream & 22 & 29 & 78 & 71 & 61 & 19 \\
\hline Lemarié et al., 1998 & seabass & $12-17$ & $14-42$ & $93-98$ & $58-86$ & $61-80$ & $24-42$ \\
\hline Wallin and Haakanson, 1991 & various spp & $21-30$ & $15-30$ & $70-79$ & $70-85$ & $49-60$ & $16-26$ \\
\hline Working figures used in this paper & $\max$ & & & 77 & 82 & & \\
\hline & $\min$ & & & & & 49 & 15 \\
\hline
\end{tabular}

extreme value in every column. The lower figure refers to the solute release only, whereas the upper (maximal) figure comprises both the solute and the particulate fraction i.e. assuming that all the particulate material has the potential to be remineralized. In this context, the maximal rate is perhaps unrealistic but it represents the "worst case scenario" in terms of water quality deterioration.

\section{The model}

A simple model was used in order to calculate the maximal quantity of solute wastes remaining in the Mediterranean. The model assumes there is a constant annual discharge of nutrients into the sea and a standard rate of water renewal.

$$
Q_{t}=\left(Q_{t-1}+D\right) \times \frac{a-1}{a}
$$

$Q_{t}$ : quantity of fish farming released nutrients in the Mediterranean at year $t$.

$D$ : annual discharge of fish farming released nutrients in the Mediterranean.

a: number of years required for a complete renewal of Mediterranean water. Therefore, the factor [ $(a-$ 1) $/ a$ ] represents the proportion of Mediterranean water retained in the basin after the outflow to the Atlantic each year.

The above equation implies that at year $t$ the quantity of waste remaining in the Basin is the sum of the amount of waste left from the past year $\left(\mathrm{Q}_{\mathrm{t}-1}\right)$, plus the annual discharge (D), multiplied by the percentage of Mediterranean water retained in the Basin each year.

Expanding the above equation the model takes the form:

$$
\begin{gathered}
Q_{t}=D \times\left[\left(\frac{a-1}{a}\right)^{1}+\left(\frac{a-1}{a}\right)^{2}+\cdots\right. \\
\left.\cdots+\left(\frac{a-1}{a}\right)^{t-1}+\left(\frac{a-1}{a}\right)^{t}\right]
\end{gathered}
$$

When $|(a-1) / a|<1$, the limit of this equation for infinite time is:

$$
Q_{\infty}=D \times\left(\frac{\left(\frac{a-1}{a}\right)}{1-\left(\frac{a-1}{a}\right)}\right)=D \times(a-1)
$$

This formula implies that the maximal amount of waste that can be retained within the system is a-1 times the annual discharge. For the Mediterranean, where the time for water renewal is 80-100 years (Margalef, 1985; Turley, 1999), the potential for accumulating any given substance is 79-99 times the annually discharged quantity. However, $Q_{\mathrm{A}}$ is approached asymptotically and therefore it takes some time before noticeable effects are found in the environment.

For this model we have used nutrients as "conservative pollutants" and it is assumed that water 
TABle 2. - Estimates of Nitrogen and Phosphorus discharges into the entire Mediterranean and the Eastern Basin and intercomparisons of their contribution to the total nutrient pool. E and F estimates correspond to total and solute wastes, respectively.

\begin{tabular}{|c|c|c|c|c|c|}
\hline Estimates & Units & \multicolumn{2}{|c|}{ Total Medit. } & $\begin{array}{c}\text { Easte } \\
\mathrm{N}\end{array}$ & $\begin{array}{l}\text { Medit. } \\
\text { P }\end{array}$ \\
\hline A: Total nutrient quantity in the Mediterranean & $10^{3}$ tons & 255020 & 25089 & 119715 & 12606 \\
\hline B: Atmos. Terr. Inputs -ATI (Bethoux et al., 1998) & $10^{3}$ tons $\mathrm{y}^{-1}$ & 5351 & 539 & 3222 & 304 \\
\hline C: Anthropogenic discharges (UNEP-Scenario 2) & $10^{3}$ tons $\mathrm{y}^{-1}$ & 2686 & 297 & 946 & 101 \\
\hline D: Anthropogenic discharges (UNEP-Scenario 1) & $10^{3}$ tons $\mathrm{y}^{-1}$ & 677 & 83 & 198 & 24 \\
\hline E: Fish farming discharges - max & $10^{3}$ tons $\mathrm{y}^{-1}$ & 18 & 3 & 12 & 2 \\
\hline $\mathrm{F}$ : Fish farming discharges - min & $10^{3}$ tons $\mathrm{y}^{-1}$ & 12 & 0.5 & 8 & 0.4 \\
\hline B/A: ATI / Total & $\% \mathrm{y}^{-1}$ & 2.098 & 2.148 & 2.691 & 2.408 \\
\hline C/A: UNEP2 / Total & $\% \mathrm{y}^{-1}$ & 1.053 & 1.183 & 0.790 & 0.800 \\
\hline D/A: UNEP1 / Total & $\% \mathrm{y}^{-1}$ & 0.266 & 0.331 & 0.166 & 0.193 \\
\hline E/A: max Fish-Farm / Total & $\% \mathrm{y}^{-1}$ & 0.007 & 0.012 & 0.010 & 0.016 \\
\hline F/A: min Fish-Farm / Total & $\% \mathrm{y}^{-1}$ & 0.005 & 0.002 & 0.007 & 0.003 \\
\hline C/B: UNEP2 / ATI & $\%$ & 50.208 & 55.051 & 29.350 & 33.235 \\
\hline D/B: UNEP1 / ATI & $\%$ & 12.654 & 15.418 & 6.151 & 8.011 \\
\hline E/B: max Fish-Farm / ATI & $\%$ & 0.345 & 0.548 & 0.382 & 0.648 \\
\hline F/B: min Fish-Farm / ATI & $\%$ & 0.220 & 0.100 & 0.243 & 0.119 \\
\hline E/C: max Fish-Farm / UNEP2 & $\%$ & 0.688 & 0.995 & 1.303 & 1.951 \\
\hline F/C: min Fish-Farm / UNEP2 & $\%$ & 0.438 & 0.182 & 0.829 & 0.357 \\
\hline E/D: max Fish-Farm / UNEP1 & $\%$ & 2.729 & 3.553 & 6.217 & 8.093 \\
\hline F/D: min Fish-Farm / UNEP1 & $\%$ & 1.737 & 0.650 & 3.957 & 1.480 \\
\hline
\end{tabular}

masses in the Mediterranean mix to a great extent. The potential limitations of these assumptions are discussed in detail in section 4 of the discussion. Furthermore, recent physical oceanographic measurements in Gibraltar imply that the water outflow from the Mediterranean is probably lower than previous estimates (Tsimplis and Bryden 2000), and therefore the time for water renewal could be higher than anticipated here.

\section{RESULTS}

Estimates for the total quantities of the nutrient pool in the Mediterranean, as well as the total atmospheric and terrestrial inputs (ATI) in Table 2, were derived from Bethoux et al. (1992), and Bethoux et al. (1998). Estimates of the anthropogenic discharges were given in UNEP (1996), using two scenarios: (a) $\mathrm{N}$ and $\mathrm{P}$ from human populations inhabiting the coastal zone in the form of sewage and (b) $\mathrm{N}$ and $\mathrm{P}$ discharged into the sea from various human activities such as agriculture, the food processing industry, sewage etc. Production figures for the Mediterranean from the Federation of European Aquaculture Producers (http://www.feap.org) showed that 96000 tons of bream and bass were produced in 1999 (estimated 109000 tons for 2000) and for the past 5 years $2 / 3$ of the total production came from the eastern Mediterranean. Fish farming nutrients were calculated for 150000 tons of production (100000 tons in the east Mediterranean), which is a reasonable figure for the next 2-3 years and assuming a 2:1 food conversion ratio (FCR). Two figures (minimum - maximum) of the proportion of nutrient loss were used, covering the range presented in Table 1. Depending on the basis of the comparison, the contribution of fish farming effluents to the Mediterranean nutrient pool varies considerably (Table 2). For instance, $\mathrm{P}$ from fish farms could be $0.2-3.5 \%$ of the annual anthropogenic discharge, or $0.1-0.55 \%$ of the annual ATI. These figures become even higher in the eastern Mediterranean reaching $8 \%$ of the $\mathrm{P}$ discharged through sewage wastes. However, when compared to the total nutrient pool in the Mediterranean, the annual discharge of fish farming becomes two to three orders of magnitude lower $(0.002-0.012 \%$ in

TABLE 3. - Accumulation of $\mathrm{P}$ discharged from fish farming in the Mediterranean for different temporal scales corresponding to proportions of the Mediterranean water renewal period ( 80 years). Minimal and maximal estimates are given for production of 150000 tons in total quantities and as a percentage of the present total $\mathrm{P}$ pool.

\begin{tabular}{lrrrrr}
\hline $\begin{array}{l}\text { renewal } \\
\text { period }\end{array}$ & years & $\begin{array}{r}\mathrm{P} \min \\
\text { (tons) }\end{array}$ & $\begin{array}{r}\mathrm{P} \max \\
\text { (tons) }\end{array}$ & $\begin{array}{r}\mathrm{P} \min \\
(\%)\end{array}$ & $\begin{array}{r}\mathrm{P} \max \\
(\%)\end{array}$ \\
\hline $1 / 8$ & 10 & 4572 & 24995 & 0.02 & 0.10 \\
$1 / 4$ & 20 & 9494 & 51900 & 0.04 & 0.21 \\
$1 / 2$ & 40 & 16871 & 92228 & 0.07 & 0.37 \\
1 & 80 & 27067 & 147968 & 0.11 & 0.59 \\
2 & 160 & 36960 & 202047 & 0.15 & 0.81 \\
3 & 240 & 40576 & 221817 & 0.16 & 0.88 \\
4 & 320 & 41898 & 229044 & 0.17 & 0.91 \\
5 & 400 & 42382 & 231686 & 0.17 & 0.92 \\
6 & 480 & 42558 & 232651 & 0.17 & 0.93 \\
7 & 560 & 42623 & 233005 & 0.17 & 0.93 \\
8 & 640 & 42646 & 233134 & 0.17 & 0.93 \\
9 & 720 & 42655 & 233181 & 0.17 & 0.93 \\
10 & 800 & 42658 & 233198 & 0.17 & 0.93 \\
\hline
\end{tabular}


TABLE 4. - Predictions of proportional increase of the nutrient concentrations in the Mediterranean as a result of anthropogenic activities.

\begin{tabular}{lrrrr}
\hline & \multicolumn{2}{c}{30 years } & \multicolumn{2}{c}{400 years } \\
& $\mathrm{N}(\%)$ & $\mathrm{N}(\%)$ & $\mathrm{P}(\%)$ & 169.70 \\
\hline ATI (Bethoux et al., 1998) & 52.45 & 53.70 & 165.75 & 83.22 \\
Anthropogenic discharges (UNEP-Scenario 2) & 26.34 & 29.56 & 93.42 \\
Anthropogenic discharges (UNEP-Scenario 1) & 6.64 & 8.28 & 0.97 & 0.17 \\
Fish farming discharges - max & 0.18 & 0.29 & 0.36 & 0.17 \\
Fish farming discharges - min & 0.12 & 0.05 & & \\
\hline
\end{tabular}

the Mediterranean and 0.003-0.016\% in the Eastern Basin). On the other hand, the anthropogenic discharges seem to contribute half the ATI and they represent more than $1 \%$ of the total nutrient pool in the Mediterranean, these figures being considerably lower in the Eastern Basin.

In order to estimate the integrated effect of nutrient discharge over time, the cumulative quantities for minimal and maximal estimates of $\mathrm{P}$ loss were calculated with the $\mathrm{Q}_{t}$ model described above. This model provides estimates on quantities and not on nutrient concentrations. However, when these quantities are compared to the total nutrient pool, the percentage increase may also be regarded as a percentage increase in concentrations since the total amount of water in the Mediterranean can be assumed to remain constant. The results (Table 3) showed that the asymptotic percentage of the fish farming contribution to the total $\mathrm{P}$ pool is less than $1 \%$ and for the first 20 years it will be less than $0.3 \%$. On the other hand, the increase due to total anthropogenic discharges in the long term (Table 4) is likely to nearly double the concentrations of nutrients in the Mediterranean and even after 30 years it is expected that it could cause an increase of 6 to $30 \%$.

\section{DISCUSSION}

\section{Contribution of fish farming to the nutrient pool in the Mediterranean}

The results from the present study imply that there is little risk of a noticeable increase in the nutrient concentration in the entire Mediterranean or even in the Eastern Basin as a result of fish farming. At worst and even if all nutrients remained in suspension, the expected increase in nutrient concentrations is within the error limits of most analytical methods. In this context, it could be concluded that fears of large scale effects related to nutrient release are not justified. However, the potential for impair- ing coastal marine ecosystems by changing the trophic status cannot be ignored, particularly when considering the environmental pressures already exerted by other anthropogenic factors on the Mediterranean coast (Turley, 1999), which are so strong that they can be paralleled to climatic factors (Duarte et al., 1999). Significant adverse environmental effects of nutrients resulting from fish farms have been reported in the Mediterranean: long-term impacts (2-4 years) of fish farming on Posidonia oceanica meadows (Delgado et al., 1999), and the proliferation of benthic microalgae on the seabed due to benthic fluxes of nutrients (Karakassis et al., 1999), are some examples of changes that might occur at spatial scales exceeding $10 \mathrm{~m}$ from the cages and at temporal scales exceeding two years after the cessation of fish farming activities.

One of the major objectives of the site selection procedure for fish farming is to avoid areas with low water renewal rates, which would impose risks for the reared stock. Therefore, the possibility of a particular farm affecting itself and its immediate environment should be rather low as has been shown in studies of water quality in the Mediterranean (Pitta et al., 1999). At the other end of the spectrum, the potential for nutrient release to alter the nutrient regime of a large basin like the Mediterranean is also low. The problem may be at intermediate scales (e.g. of a Gulf) and particularly when poor flushing is involved. In this case, it is possible that nutrient concentrations may rise considerably depending on the volume of the Gulf, the amount of nutrients discharged and the time needed for water renewal. It has been argued (Pitta et al., 1999), that these effects are more likely to occur during the summer period when there is high light availability and maximal discharge of farm-nutrients in the normally nutrient depleated surface layers of the water column.

The Mediterranean fish farming industry is still in its adolescence and therefore, it is quite likely that technology will improve, leading to more efficient use of fish feed and less nutrient loss per ton of fish 
produced. In that case, despite the expected further increase in production, the figures for nutrient loss will not increase proportionally as happened with the salmon industry in the 1990s where the food conversion ratio dropped to $0.8: 1$ allowing a less environmentally damaging (and more profitable) development of the industry than in the previous 2 decades. According to Chopin et al. (2001), the annual discharge of $\mathrm{N}$ and $\mathrm{P}$ per ton of salmon produced decreased by $55 \%$ and $26 \%$ respectively in less than 10 years. Furthermore, considerable effort is being made to develop sustainable mariculture systems in which the effluent is used for secondary production such as seaweed-abalone production (Neori et al., 2000), or the use of biofilters. It is also worth noting that as well as fish farming, mussel cultures have also increased considerably in the Mediterranean during the last decades. This type of aquaculture has the opposite effect on the water column because it removes large quantities of particulate $\mathrm{N}$ and $\mathrm{P}$ and in fact it has been suggested (Kautsky and Folke, 1989), that it may be used as a means of reducing the environmental impacts of fish farming. The emerging issue of integrated mariculture with the use of inorganic and organic extractive aquaculture (Chopin et al., 2001), close to fish farms could further reduce nutrients discharged into the marine environment transforming wastes into raw material for a profitable industry.

\section{Critique of the methods used to assess fish farming impacts}

In the present paper we have compared the amount of nutrients resulting from fish farming activities to those resulting from other anthropogenic sources as well as to the total nutrient quantities in the Mediterranean and the Eastern Basin. The percentages obtained through these comparisons can be as high as $8 \%$ or as low as $0.1 \%$ depending on the basis of the comparison. In all cases the input represents less than $0.02 \%$ of the total nutrient quantity in the Mediterranean.

This huge variation (three orders of magniture) might be very important when explaining the effects to the regulating authorities and to the public. Frightening features emerge when comparing nutrients released from fish farming to anthropogenic wastes, particularly when the basis for the comparison is only the amount of nutrients derived from human excreta. A number of papers have used this type of comparison involving person equivalents
(Folke et al., 1994), calculating the percentage of mariculture effluents over all types of nutrient discharges in Finland (Maakinen, 1991), or comparing nutrients from fish farms in Norway to the total population of the country (Leffertstra, 1991). However, these figures are of little use when no account is taken of the total assimilative capacity of the recipient water. For instance, it is possible that a $300 \%$ increase in nutrient discharges may be harmless when the receiving water body is adequately flushed or when the quantity over which this increase is calculated is very small, whereas a $5 \%$ increase might cause severe degradation when the system is close to the maximum assimilative capacity (Krom, 1986).

\section{Other sources of nutrient enrichment}

Anthropogenic discharges seem to contribute considerably to the Mediterranean nutrient reserves. According to Bethoux et al. (1999), over the last 30 years there has been a steady $0.5 \%$ annual increase in the nutrient concentrations in the Mediterranean, which means that today's concentrations are about $16 \%$ (i.e. $1.005^{30}$ ) higher than those in the late 1960 s when it was assumed that the nutrient regime (at least in the Western Basin) was fairly close to a steady state. According to the model we used (Table 4), it is likely that with the figures estimated in scenario 2 of the UNEP (1996) report, there is a risk of a $30 \%$ increase during the next 30 years and of $100 \%$ increase in the long term. The long term nutrient increase due to ATI is probably a gross exaggeration since a very large proportion (50-90\%) of this nutrient source has always been there and forms part of the natural processes in the Mediterranean. Changes in the nutrient content, and consequently in primary productivity (Solic et al., 1997), might be the reasons for some "positive effects" such as the increase in fish landings and catch per effort (Caddy et al., 1995), despite the long term decline in Mediterranean water quality (Duarte et al., 1999 and references therein). However, the long term changes in nutrient concentration are likely to have severe effects on the biodiversity of the Mediterranean which harbours a large proportion of endemic species in various taxa (Tortonese, 1985; Fredj et al., 1992).

\section{Limitations of our approach}

In the present paper, and particularly when using the $\mathrm{Q}_{t}$ model, nutrients were treated as "conservative pollutants" i.e. it was assumed that they remain in 
solute form for an infinite time and that water masses mix to a great extent. These assumptions are only partly fulfilled. The latter is violated by the distinct circulation patterns in various parts of the Mediterranean and the "stagnant water zones" in some abyssal areas. It is also possible that Qt overestimates the amount of fish farm nutrients retained in the Mediterranean since the concentration of nutrients in water masses of the outflow subsurface current in Gibraltar is always higher than in the inflow from the Atlantic.

The former assumption (i.e. nutrients as conservative pollutants) is even more difficult to fulfil, since the fate of nutrients is governed by a complex set of biogeochemical factors. A large part of the nutrients is consumed and released again by phytoand bacterioplankton, another part is transferred to higher trophic levels, and a further part is lost from the marine environment through various processes such as denitrification (a $\mathrm{N}$ sink) or through $\mathrm{P}$ adsorption in sinking mineral particles (Krom et al., 1991). It has recently been estimated (Eijsink et al., 2000), that in the Eastern Basin only, some $5.5^{*} 10^{12}$ mmols of P (i.e. 178 tons of P) are buried annually in the sediment, which is about $58 \%$ of the annual ATI estimated by Bethoux et al. (1998). These findings by Eijsink et al. (2000), put in question the accuracy of previous estimates of the ATI in the eastern Mediterranean, which assumed negligible $\mathrm{P}$ burial. The issue gets more complicated by the fact that part (probably ca 70\%) of the above mentioned $\mathrm{P}$ burial flux rate is due to the river Nile which stopped after the construction of the Aswan dam and therefore an important source of nutrients for the Mediterranean was lost. It is also worth noting that different nutrient species have different recycling rates (Bishop et al., 1977; Garber, 1984), and different effects on ecosystem productivity which may be $\mathrm{P}$ or $\mathrm{N}$ limited in different parts of the Mediterranean and at different times of the year (Berland et al., 1980; Krom et al., 1991; Thingstad and Rassoulzadegan, 1995). Information on the fate of nutrients and on the role of each nutrient species in controlling primary production in the Mediterranean and particularly in the Eastern Basin would allow the risks that might be caused from the expected increase in nutrient concentrations due to anthropogenic discharges to be assessed more precisely. Recently published information from the eastern Mediterranean (Machias et al., 2004; Machias et al., in press), indicates that there is a considerable increase in fishery production in the vicinity of aquaculture zones, implying that there is an efficient transfer of nutrients up the food chain.

Despite these limitations, it is clear that the model provides a good indication of the maximal nutrient loads i.e. of the "worst case scenario" which should be taken into account when decisions are made. Furthermore, this type of analysis is advisable for local scales as well in order to avoid adverse effects on both the coastal ecosystems and the reared stocks.

\section{ACKNOWLEDGEMENTS}

This study was partly funded by the Greek General Secretariat for Research and Technology through the project \#565 "Interactions of aquaculture and the marine environment" in the framework of the second Operational Programme for RandT. Further collaboration between the authors was made possible in the framework of the project "CYCLOPS: Cycling of Phosphorus in the Mediterranean" (EVK3-1999-00009), which is supported by the European Commission (Research Directorate General-Environment Programme-Marine Ecosystems). The CYCLOPS project is part of the EC IMPACTS cluster. Assistance in the Spanish text by Olga Invers and the comments provided by 2 anonymous reviewers are also acknowledged.

\section{REFERENCES}

Ballestrazzi, R., D. Lanari, E. D’Agaro and A. Mion. - 1994. The effect of dietary protein level and source on growth, body composition, total ammonia and reactive phosphate excretion of growing sea bass (Dicentrarchus labrax). Aquaculture, 127: 197-206.

Berland, B.R., D.J. Bonin and S.Y Marstrini. - 1980. Azote ou phosphore? Considérations sur le 'paradox nutritionnel' de la mer méditerranée. Oceanol. Acta, 3: 135-142.

Bethoux, J.P., B. Gentili, P. Morin, E. Nicolas, C. Pierre and D. Ruiz-Pino. - 1999. The Mediterranean Sea: a miniature ocean for climatic and environmental studies and a key for the climatic functioning of the North Atlantic. Prog. Oceanogr., 44: 131-146.

Bethoux, J.P., P. Morin, C. Madec and B. Gentili. - 1992. Phosphorus and nitrogen behaviour in Mediterranean Sea. Deep-Sea Res., 39: 1641-1654.

Bethoux, J.P., P. Morin, C. Chaumery, O. Connan, B. Gentili and D. Ruiz-Pino. - 1998. Nutrients in the Mediterranean Sea, mass balance and statistical analysis of concentrations with respect to environmental change Mar. Chem., 63: 155-169.

Bishop, J.K.B., R.W. Collier, D.R. Ketten and J.M. Edmond. 1977. The chemistry, biology and vertical flux of particulate matter from the upper $400 \mathrm{~m}$ pf the equatorial Atlantic Ocean. Deep-Sea Res., 24: 511-548.

Caddy, J.F., R. Refk and T. Do-Chi. - 1995. Productivity estimates for the Mediterranean: evidence of accelerating ecological change. Ocean Coast. Management, 26: 1-18.

Chopin, T., A.H. Buschmann, C. Halling, M. Troell, N. Kautsky, A. Neori, G.P. Kraemer, J.A. Zertuche-Golzalez, C. Yarish and C. 
Neefus. - 2001. Integrating seaweeds into marine aquaculture systems: a key toward sustainability. J. Phycol., 37: 975-986.

Delgado, O., J. Ruiz, M. Perez, J. Romero and E. Ballestreros. 1999. Effects of fish farming on seagrass (Posidonia oceanica) in a Mediterranean bay: seagrass decline after loading cessation. Oceanol. Acta, 22: 109-117.

Dosdat, A., E. Servais, R. Metailler, C. Huelvan and E. Desbruyeres. - 1996. Comparison of nitrogenous losses in five teleost fish species. Aquaculture, 141: 107-127.

Duarte, C.M., S. Agusti, H. Kennedy and D. Vaqué. - 1999. The Mediterranean climate as a template for Mediterranean marine ecosystems: the example of the northeast Spanish littoral. Prog. Oceanogr., 44: 245-270.

Eijsink, L.M., M.D. Krom and B. Herut. - 2000. Speciation and burial flux of phosphorus in the surface sediments of the Eastern Mediterranean. Amer. J. Sci., 300: 483-503.

Folke, C. and N. Kautsky. - 1989. The role of ecosystems for a sustainable development of aquaculture. Ambio, 18: 234-243.

Folke, N., N. Kautsky and M. Troell. - 1994. The costs of eutrophication from Salmon farming: Implications for Policy. J. Environ. Management, 40: 173-182.

Fredj, G., D. Bellan-Santini and M. Menardi. - 1992. Etat des connaissances sur la faune marine Mediterraneenne. Bull. Inst. Oceanogr. Monaco, 9, 133-145.

Gabrielides, G.P., Y. Henoque, G. Kamizoulis, E. Cotou, R. Ceccarelli, L. Triolo and M. Schimberini. - 1999. Human activities and pressures. In: G. Izzo and S. Moretti (eds.), State and pressures of the marine and coastal Mediterranean environment. Environ. assessment series, 5: 47-75.

Garber, H. - 1984. Laboratory study of nitrogen and phosphorus remineralization during the decomposition of coastal plankton and seston. Estuar. Coast. Shelf Sci., 18, 685-702.

GESAMP. - 1990. The state of the marine environment. UNEP Regional Seas Reports and Studies 115,1990.

Gowen, R.J. and N.B. Bradbury. - 1987. The ecological impact of salmonid farming in coastal waters: A review. Oceanogr. Mar. Biol. Annual Review, 25: 563-575.

Hall, P.O.J., O. Holby, S. Kollberg and M.O. Samuelsson. - 1992. Chemical fluxes and mass balances in a marine fish cage farm. IV. Nitrogen. Mar. Ecol. Prog. Ser., 89, 81-91.

Holby, O. and P.O.J. Hall. - 1991. Chemical fluxes and mass balances in a marine fish cage farm. II. Phosphorus. Mar. Ecol. Prog. Ser. 70: 263-272.

Karakassis, I. and E. Hatziyanni. - 2000. Benthic disturbance due to fish farming analyzed under different levels of taxonomic resolution. Mar. Ecol. Prog. Ser., 203: 247-253.

Karakassis, I., E. Hatziyanni, M. Tsapakis and W. Plaiti. - 1999. Benthic recovery following cessation of fish farming: a series of successes and catastrophes. Mar. Ecol. Prog. Ser., 184: 205-218.

Karakassis, I., M. Tsapakis, E. Hatziyanni and P. Pitta. - 2001. Diel variation of nutrients and chlorophyll in sea bream and sea bass cages in the Mediterranean. Fresenius Environ. Bull., 10: 278283.

Karakassis, I., M. Tsapakis and E. Hatziyanni. - 1998. Seasonal variability in sediment profiles beneath fish farm cages in the Mediterranean. Mar. Ecol. Prog. Ser., 162: 243-252.

Karakassis, I., M. Tsapakis, E. Hatziyanni, K.N. Papadopoulou and W. Plaiti. - 2000. Impact of cage farming of fish on the seabed in three Mediterranean coastal areas. ICES J. Mar. Sci., 57: 1462-1471.

Karakassis, I., M. Tsapakis, C.J. Smith and H. Rumohr. - 2002. Fish farming impacts in the Mediterranean studied through sediment profiling imagery (SPI). Mar. Ecol. Prog. Ser., 227: 125133.

Kaushik, S.J. - 1998. Nutritional bioenergetics and estimation of waste production in non-salmonids. Aquat. Living Resour., 11: 211-217.

Kautsky, N. and C. Folke. - 1989. Management of coastal areas for a sustainable development of aquaculture. Biota, 5: 1-11.

Krom, M.D. - 1986. An evaluation of the concept of assimilative capacity as applied to marine waters. Ambio, 15: 208-214.

Krom, M.D., S. Ellner, J. van-Rijn and A. Neori. - 1995. Nitrogen and phosphorus cycling and transformations in a prototype 'non-polluting' integrated mariculture system, Eilat, Israel. Mar. Ecol. Prog. Ser. 118: 25-36.

Krom, M.D., N. Kress, S. Brenner and L.I. Gordon. - 1991. Phosphorus limitation of primary productivity in the eastern Mediterranean Sea. Limnol. Oceanogr., 36: 424-432.
Krom, M.D., C. Porter and H. Gordin. - 1985. Nutrient budget of a marine fish pond in Eilat, Israel. Aquaculture, 51: 65-80.

La Rosa, T., S. Mirto, A. Mazzola and R. Danovaro. - 2001. Differential responses of benthic microbes and meiofauna to fishfarm disturbance in coastal sediments. Environ. Pollut., 112: 427-434.

Lanari, D., B.M. Poli, R. Ballestrazzi, P. Lupi, E. D’Agaro and M. Mecatti. - 1999. The effects of dietary fat and NFE levels on growing European sea bass (Dicentrarchus labrax L.) . Growth rate, body and fillet composition, carcass traits and nutrient retention efficiency. Aquaculture, 179: 351-364.

Leffertstra, H. - 1991. Steps towards a sustainable fish farming industry, environmental goals and new regulations to achieve these for fish farming in Norway. In: De Pauw N., Joyce J. (Eds.), Aquaculture and the environment. Europ. Aquaculture Society Special Publication, 16: 461-466.

Lemarié, G., J.L.M. Martin, G. Dutto and C. Garidou. - 1998. Nitrogenous and phosphorous waste production in a flowthrough land-based farm of European sea bass Dicentrarchus labrax. Aquat. Living Resour., 11: 247-254.

Luspatsch, I. and G.W. Kissil. - 1998. Predicting aquaculture waste from gilthead seabream Sparus aurata culture using a nutritional approach. Aquat. Living Resour., 11: 265-268.

Machias, A., I. Karakassis, M. Labropoulou, S. Somarakis, K.N. Papadopoulou and C. Papaconstantinou. - 2004. Changes in wild fish assemblages after the establishment of a fish farming zone in an oligotrophic marine environment. Estuarine coastal shelf Sci., 60: 771-779

Machias, A., I. Karakassis, S. Somarakis, M. Giannoulaki, K.N. Papadopoulou and C. Smith. - 2005. The response of demersal fish communities to the presence of fish farms. Mar. Ecol. Prog. Ser, 288: 241-250.

Mäkinen, T. - 1991. Nutrient load from marine aquaculture. In: Mäkinen T. (Ed), Marine aquaculture and environment. Nordic Council of Ministers, Copenhagen, 1-8.

Margalef, R. - 1985. Environmental control of the mesoscale distribution of primary producers and its bearing to primary production in the Western Mediterranean. In: Moraitou-Apostolopoulou M., Kiortsis V. (Eds.), Mediterranean marine ecosystems. Plenum Press, New York, 213-230.

Mazzola, A., S. Mirto and R. Danovaro. - 1999. Initial fish-farm impact on meiofaunal assemblages in coastal sediments of the Western Mediterranean. Mar. Pollut. Bull., 38: 1126-1133.

Mazzola, A., S. Mirto and R. Danovaro. - 2000. Fish-farming effects on benthic community structure in coastal sediments: analysis of meiofaunal resilience. ICES J. Mar. Sci., 57: 14541461

McDougall, N. and K.D. Black. - 1999. Determining sediment properties around a marine cage farm using acoustic ground discrimination: RoxAnn ${ }^{\mathrm{TM}}$. Aquaculture Res., 30: 451-458.

Mirto, S., T. La Rosa, C. Gambi, R. Danovaro and A. Mazzola. 2002. Nematode community response to fish-farm impact in the western Mediterranean. Environ. Pollut., 116: 203-214.

Munday, B.W., A. Eleftheriou, M. Kentouri and P. Divanach. 1994. Quantitative statistical analysis of the literature concerning the interaction of the environment and aquaculture - identification of gap and lacks. J. Appl. Ichthyol., 10: 319-325.

Naylor, R.L., R.J. Goldburg, J.H. Primavera, N. Kautsky, M.C.M. Beveridge, J. Clay, C. Folke, J. Lubchenco, H. Mooney and M. Troell. - 2000. Effect of aquaculture on world fish supplies. Nature, 405: 1017-1024.

Neori, A., M. Shpigel and D. Ben-Ezra. - 2000. A sustainable integrated system for culture of fish, seaweed and abalone. Aquaculture, 186: 279-291.

Papoutsoglou, S., M.J. Costello, E. Stamou and G. Tziha. - 1996. Environmental conditions at sea-cages and ectoparasites on farmed European sea-bass, Dicentrarchus labrax (L.) and gilthead sea-bream, Sparus aurata L, at two farms in Greece. Aquaculture Res., 27: 25-34.

Pergent, G., S. Mendez, C. Pergent-Martini and V. Pasqualini. 1999. Preliminary data on the impact of fish farming facilities on Posidonia oceanica meadows in the Mediterranean. Oceanol. Acta, 22: 95-107.

Pitta, P., I. Karakassis, M. Tsapakis and S. Zivanovic. - 1999. Natural vs. mariculture induced variability in nutrients and plankton in the Eastern Mediterranean. Hydrobiologia, 391: 181-194.

Porter, C.B., M.D. Krom, M.G. Robins, L. Brickell and A. Davidson. - 1987. Ammonia excretion and total $\mathrm{N}$ budget for guilt- 
head seabream (Sparus aurata) and its effect on water qyuality conditions. Aquaculture, 66: 287-297.

Ruiz, J.M., M. Perez and J. Romero. - 2001. Effects of fish farm loadings on seagrass (Posidonia oceanica) distribution, growth and photosynthesis. Mar. Pollut. Bull., 42: 749-760

Silvert, W. - 1992. Assessing environmental impacts of fihfish aquaculture in marine waters. Aquaculture 107: 69-79.

Solic, M., N. Krstulovic, I. Marasovic, A. Baranovic, T. PucherPetkovic and T. Vucetic. - 1997. Analysis of time series of planktonic communities in the Adriatic Sea: distinguishing between natural and man-induced changes. Oceanol. Acta, 20: 131-143.

Thingstad, T.F. and F. Rassoulzadegan. - 1995. Nutrient limitations, microbial food webs, and 'biological C-pumps': Suggested interactions in a P-limited Mediterranean. Mar. Ecol. Prog. Ser., 117: 299-306.

Tortonese, E. - 1985. Distribution and ecology of endemic elements in the Mediterranean fauna (fishes and Echinoderms). In: Moraitou-Apostolopoulou M., Kiortsis V. (Eds.), Mediterranean marine ecosystems. Plenum Press, New York, 57-83.

Tsimplis, M.N. and H.L. Bryden. - 2000. Estimation of the transports through the Strait of Gibraltar. Deep Sea Res, 47: 22192242.

Turley, C.M. - 1999. The changing Mediterranean Sea-a sensitive ecosystem? Prog. Oceanogr. 44, 387-400.

UNEP. - 1996. Assessment of the state of eutrophication in the Mediterranean Sea. MAP Technical Report Series 106. UNEP, Athens, 1996.

Wallin, M. and L. Haakanson. - 1991. Nutrient loading models for estimating the environmental effects of marine fish farms. In: T. Mäkinen (ed.), Marine aquaculture and environment. Nordic Council of Ministers, Copenhagen, 9-23.

Scient. ed.: S. Zanuy 
